\title{
6. EARLY MUSICAL EDUCATION AS A PREMISE FOR THE DEVELOPMENT OF THE CHILD'S UPRIGHT PERSONALITY
}

\begin{abstract}
A person upright development is essentially connected to communication, and music is the language with the highest degree of communication, is the purest and deepest language, able to express the hidden, the essential, the spiritual. Musical education, achieved in all forms, contexts, periods, etc. under the mark of the upright development of human personality, means "wisdom, balance, love, inner light, harmony, "feeling", etc.". [I. Gagim]. Childhood, for this purpose, remains the fundamental stage for the subsequent development and initiation of the child in the "real" world, constituting at the same time, the foundation for his/her human " becoming".
\end{abstract}

Key words: early musical education, upright personality, communication, musical language, upright development

\section{Introduction}

Early education, as a first step of training for formal education, ensures the child's entrance into the mandatory education system (around the age of 6-7 years), by building the capacity to learn. Investment in early education is the most rewarding investment in education, as a study drafted by $R$. Cuhna, one of the recipients of the Nobel Prize in Economics, indicates. Early learning favours future learning opportunities.

Early education in the education system in the Republic of Moldova is based on the holistic approach on the child's development and the approach focused on the child in the educational process. In this context, Curriculumul pentru Educație Timpurie (ediţia 2018) (Curriculum for Early Education (edition 2018) operates with the following key notions: early education, holistic approach on the child, the child's welfare, curriculum focused on competences, correlation of development areas with activity areas, joy and pleasure of learning through game, secure, stimulating, rich and diverse, positive educational environment, social-educational partnership. Thus, physical, social-emotional, cognitive and language development during childhood constitutes development areas, decisive aspects for the future adult (Reference Framework of Early Education).

\section{Discussions}

Guided learning activities allowing the organisation of learning experiences, built starting from the needs identified at the level of the children

\footnotetext{
269 Associate Professor PhD., „Alecu Russo” State University from Bălţi, Republic of Moldavia, email: cosumov@mail.ru
} 
group, on areas of development in various areas of knowledge, included the areas of activity presented within the Early education curriculum, these being (Figure1):

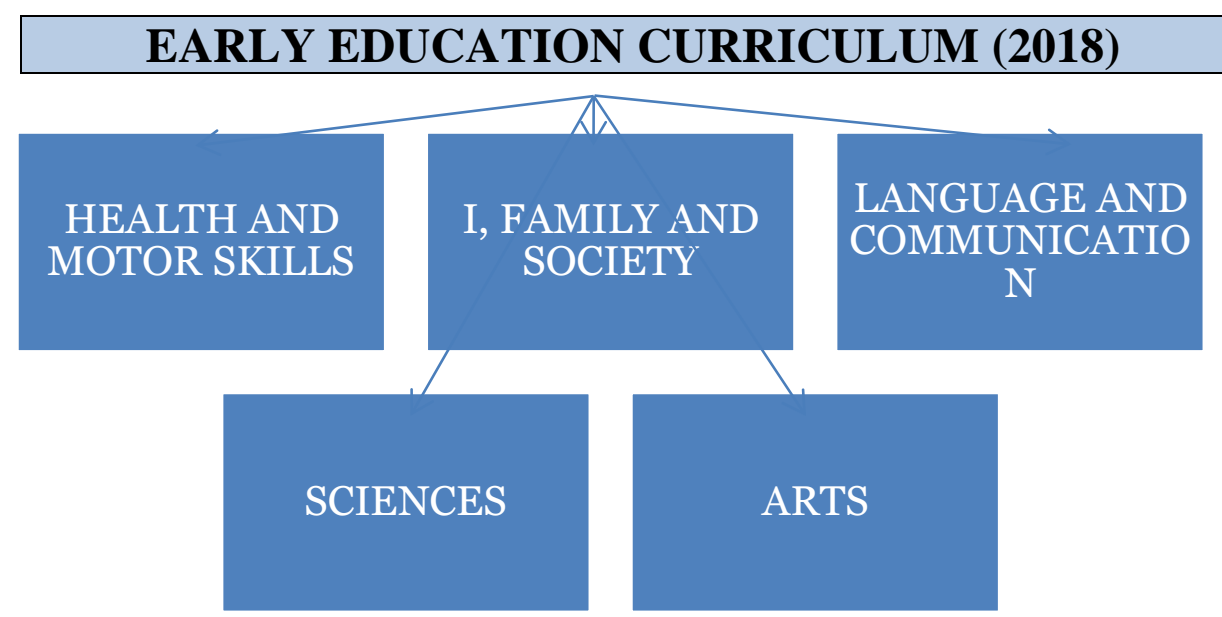

Fig. no. 1. Areas of activity in the process of early education

Studies that have monitored the development of children indicated that art responds to their biological, psychological and social needs and contributes to their welfare. Artistic development is influenced both by heredity and the environment. Active and continuous learning form an active trainable person, whose learning is contextual and disposes of an intrinsical interest, seeks for meaning in its artistic and personal experience and tries to build proper representations and internal concepts. The development of all these skills ever since early childhood has various implications for the subsequent development and learning processes.

Art prepares the child to live in beauty, in harmony, to respect the beautiful and to vibrate before it. Words, sounds, gestures, colours, plastic forms are means of expression, of exteriorization of desires, of expectations, of relationships with others, of problems. Art means become for a child authentic tools of courageous solution and with the help of science of problems of balance, harmonisation, of moulding the space where he/she lives and plays, of self-moulding. Through art sensory, artistic sensitivity and behavioural delicacy develop. Artistic sensitivity is build based on affectivity, intuition and phantasy, depending the educational skillfulness of the one educating and of the characteristics of the environment he/she develops in. Although, genetically determined, artistic sensitivity is moulded through education, because "the child's personality is the result of the conjugated action of hereditary, environmental and education factors, and it cannot be properly configured through their parallel consideration and action". More than any other activity, the activities included in the aesthetic and creative area (music education, visual arts), constitute the most generous framework and means for activating and stimulating the children's creative potential.

Education through art, as part of aesthetic education, aims at the cultivation of children's capacities of appreciating the beauty in art, ambiance, nature, social 
life and to contribute to the creation of beauty through other forms of manifestation specific to the age, contributing thus to the building and perfection of personality. Through specific work forms and directions, this specific form of education constituted one of the central concerns of school of all times.

In the literature representing the given area, we notice two direction of artistic education:

- education through art, aiming at spiritual development for an artistic activity with formative and educational effects, and

- education through art, proposing the training of the consumer for the reception of great artistic values and their integration in his/her spiritual life, both as receptor and as producer.

Education through and/or for art, is that dimension of training which aims at the person's training to receive, interpret, internalise and create values, objectified in various supports or situations (art, nature, human conduct, community, etc.), from the point of view of spiritual fulfilment and imprinting a superior meaning of the person's existence. In this context, education through and/or for art of the child entails a guided process of building artistic communication capacities and building his/her creativity The basic purpose of the educational-artistic area aiming at building the creative personality, receptive to the beauty in life and art, with capacities of assimilating artistic values.

The current view of European education, approaches the notion of artistic education/through art as a continuous individual process of the spiritual selfperfection of personality through multiple forms of contact with fine arts, these being methods of reflection of the universe in which the individual finds himself/herself as a component element. Through art the following are developed: sensitivity, taste for beauty, the knowledge of reality replenishes itself with significant data, that give nuances, the colouring, the finesse of artistic images.

Musical art reveals the inner world of a person, the most subtle nuances of emotional life, is through the emotional excellence, translates the reality so that it puts in vibration the sensitivity of the one receiving the musical work. G. Enescu stated: "What is important in art, is to vibrate yourself and to also make others vibrate." Music is also present as a means of recreation and as a means of development and as a means of expressing experiences, feelings, meeting several functions, the most important ones being:

1. cognitive function consisting in that music is a specific means of communicating thoughts and ideas through artistic images, with a strong emotional nature being present in countless manifestations of out life. Music, similar to other genres of art, has the function of knowledge. In it life phenomena, enriching children of an early age with new representations, find expression.

2. the social-educational function manifests itself through the fact that it develops convictions and offers models to follow addressing to all children. Music enchants us, cheers us or saddens us, reveals a rich content of ideas, helps us understand more deeply thoughts and events, mobilizes our forces, urges us to noble 
achievements.

3. the aesthetic function derives from the capacity to cultivate the aesthetic taste and to contribute to the enrichment of the spiritual life of children, bringing them joy and satisfaction. Music, the most profound and complex of arts, is the expression of ideas and feelings through the conveyance of musical sounds. Its messages are addressed to affectivity, sensitivity. It gives rise to certain strong aesthetic feelings supporting the intellectual and emotional development of children.

Early musical education aims at building/consolidation of three basic elements:

familiarization with musical works, education of love for them, memorising them, collecting musical impressions;

grafting the skills to listen and interpret music;

- the education of love towards music in the process of accumulating auditory impressions, elementary information about music.

\section{Results}

In this context, starting from the almost general perceptiveness of children for the world of sounds, the musical leader shall seek to develop the voice and musical hearing, melodic, rhythmic sense, building elementary skills and mastery of auditing and expressively interpreting music.

In order to train children of an early age, the bases of musical culture must take into account their age possibilities. The little ones with ages of 1,5-3 years distinguish the general disposition, the nature of the music, therefore they perceive its emotional content. Due to unstable attention in children in lower groups they perceive better not too large creations, with vivid images, especially songs, being especially captivated by the expressive intonations of the voice, the mimicry of the interpreter. Characteristic for this age are exterior manifestations of emotions - gestures of awe, of admiration, which are expressed through jumping up and down, clapping hands. Nonetheless, the sensations caused by music appear quickly and fade quickly.

Preschoolers of 4-5 years dispose of a certain emotional stability, for dance melodies, reacting very lively, sometimes agitated and cheerful. Creations with an easy, alert nature causes them a more calm state. At this age the interest for the content of the work is also manifested, there emerge questions regarding the desire to learn what the music speaks about, certain manifestation of musical memory are contoured, the desire to recount the impressions acquired regarding the listening to the song or a play.

For children of 5-7 years, voluntary attention is quite developed, the skill to focus, to notice the music in more detail. Their musical curiosity, the interest are aware and manifest through the need for contact several times with loved works. One also notices a certain spirit of observation. Children feel capable to feel the general disposition of music and to follow the revelation of artistic image. 
Dealing with the aesthetic and intellectual development of the child, it is necessary to support on all his/her creative paths of manifestation, either meaningful, but which activate perceptions and representations, awaken phantasy and imagination. When the grown-ups put before the children creation tasks, the activity of searching arises, which requires an active intellectual spirit. For instance, in his/her search the child improvises, creates new versions of the melody, trying that the literary text shall correspond to the expressive intonations, while through the musical-rhythmic activity children invent and combine with pleasure dance movements, singing and moving to the rhythm of the music. Dance, but especially folk dance, pantomime, musical drama urges children to represent small images of life, to characterise a certain character, using for it expressive movements, mimicry, the word. At the same time, a certain sequence is also complied with: children listen to the music, discuss the theme, distribute roles and finally participate in the action. In each stage there are new tasks, which force the participants to judge, to create, etc.

\section{Conclusions}

Musical education as a primordial form of education of the child facilitates the building/development of the upright personality of the future adult. The alternation of various tasks, of forms of activity (singing, listening music, playing musical instruments for children, musical-rhythmic movements) require the children's attention, presence of spirit, spirit of organisation, volitive efforts, etc., all these perfecting processes of moderation, education the will.

\section{References}

1. Gagim I. Dimensiunea psihologică a muzicii. Iaşi: Timpul, 2003. 280 p.

2. Joiţa E. Pedagogia: ştiinţa integrativă a educaţiei. Iaşi: Polirom, 1999. 189 p.

3. Morari M., Pâslaru V. Educaţie artistică în preşcolaritate: Ghid teoreticometodologic. /M. Morari, V. Pâslaru, L. Alekseeva [et al.]; coord.; Univ. de Stat „Alecu Russo” din Bălţi. - Chişinău: Pontos, 2016. 336 p.

4. Nicolescu M. Modelul uman şi idealul educativ: Antologie de texte. Bucureşti: Ed. Didactică şi Pedagogică, 1995. 124 p.

5. Roco M. Creativitate şi inteligenţă emoţională. Bucureşti, 2001. 216 p. 